๑

\title{
Drugs in development for treatment of patients with cancer-related anorexia and cachexia syndrome [Retraction]
}

The Editor-in-Chief, Dr Pilch, of Drug Design, Development and Therapy has been alerted to unacceptable levels of duplication between a previously published paper: Macciò $\mathrm{A}$, Madeddu C, Mantovani G. Current pharmacotherapy options for cancer anorexia and cachexia. Expert Opin. Pharmacotherapy 2012 13(17) 2453-2472 and one published subsequently in Drug Design, Development and Therapy: Mantovani G, Madeddu C, Macciò A. Drugs in development for treatment of patients with cancer-related anorexia and cachexia syndrome. Drug Design, Development and Therapy 2013:7 645-656.

\section{Publish your work in this journal}

Drug Design, Development and Therapy is an international, peerreviewed open-access journal that spans the spectrum of drug design and development through to clinical applications. Clinical outcomes, patient safety, and programs for the development and effective, safe, and sustained use of medicines are a feature of the journal, which has also been accepted for indexing on PubMed Central. The manuscript management system is completely online and includes a very quick and fair peer-review system, which is all easy to use. Visit http://www.dovepress.com/testimonials.php to read real quotes from published authors

\footnotetext{
Submit your manuscript here: http://www.dovepress.com/drug-design-development-and-therapy-journal
}

submit your manuscript $\mid$ www.dovepress.com

Dovepress

http://dx.doi.org// 0.2147/IDDT.S57434 